\title{
\#USGS
}

science for a changing world

Srepared in cooperation with the U.S. National Parkservice

Mountain Goat Abundance and Population Trends in the
Olympic Mountains, Washington, 2011
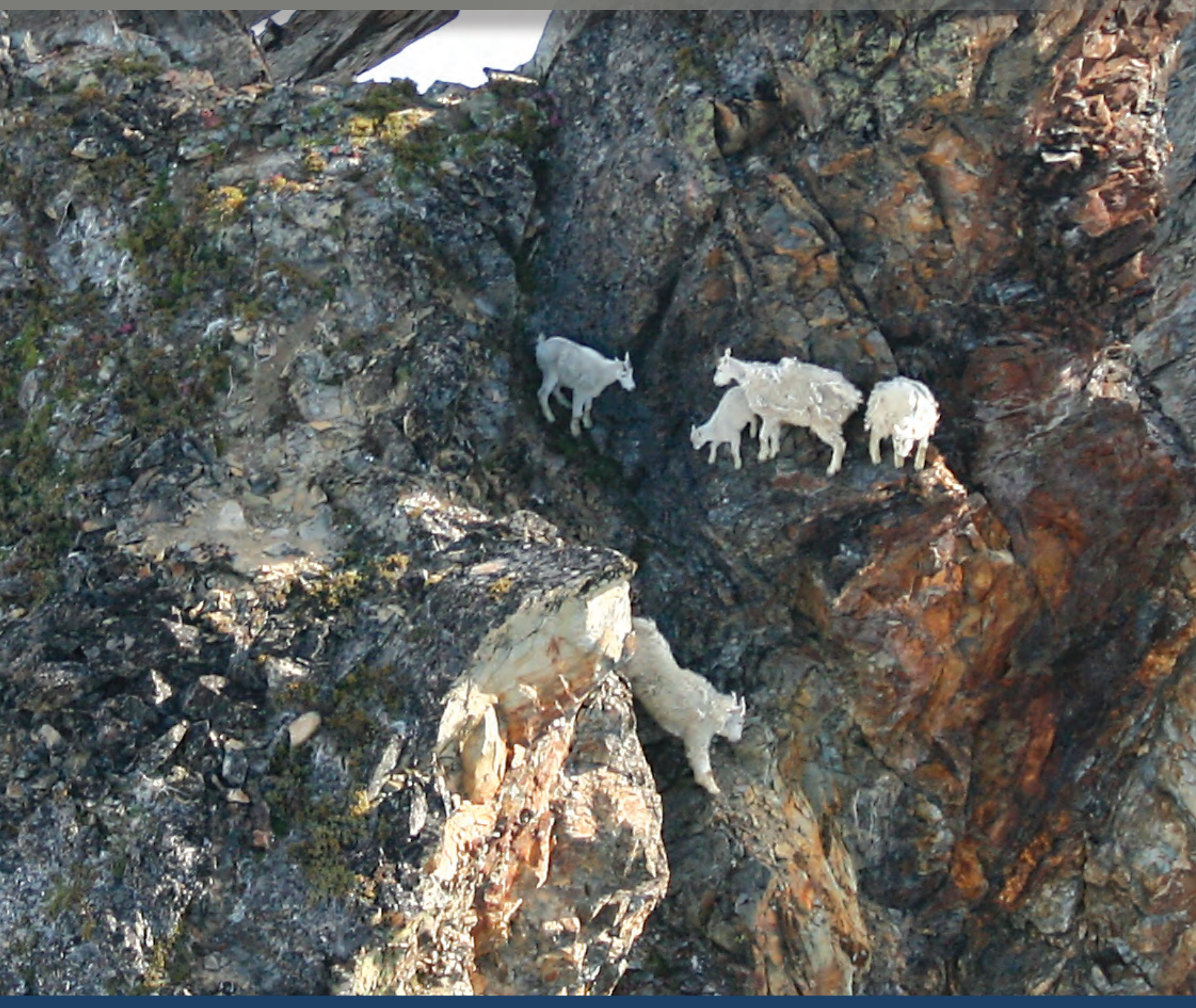

Open-File Report 2011-1313

U.S. Department of the Interior

U.S. Geological Survey

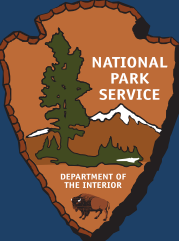


Cover: Photograph of mountain goats in Olympic National Park, Washington, 2011.

Photograph from National Park Service. 


\section{Mountain Goat Abundance and Population Trends in the Olympic Mountains, Washington, 2011}

By Kurt Jenkins, U.S. Geological Survey; Patricia Happe, National Park Service; Paul Griffin, U.S. Geological Survey; and Katherine Beirne, Roger Hoffman, and William Baccus, National Park Service

Open File Report 2011-1313 


\section{U.S. Department of the Interior \\ KEN SALAZAR, Secretary}

\section{U.S. Geological Survey \\ Marcia K. McNutt, Director}

U.S. Geological Survey, Reston, Virginia: 2012

For more information on the USGS-the Federal source for science about the Earth, its natural and living resources, natural hazards, and the environment, visit http://www.usgs.gov or call 1-888-ASK-USGS.

For an overview of USGS information products, including maps, imagery, and publications, visit http://www.usgs.gov/pubprod

To order this and other USGS information products, visit http://store.usgs.gov

Jenkins, K., Happe, P., Griffin, P., Beirne, K., Hoffman, R., and Baccus, B., 2012, Mountain goat abundance and population trends in the Olympic Mountains, Washington, 2011: U.S. Geological Survey Open-File Report 2011-1313, 22 p.

Any use of trade, product, or firm names is for descriptive purposes only and does not imply endorsement by the U.S. Government.

Although this report is in the public domain, permission must be secured from the individual copyright owners to reproduce any copyrighted material contained within this report. 


\section{Contents}

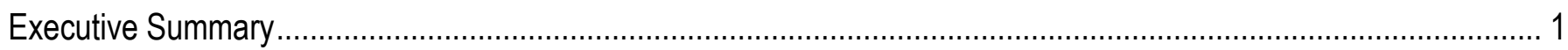

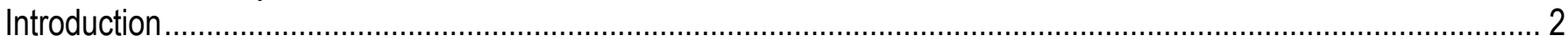

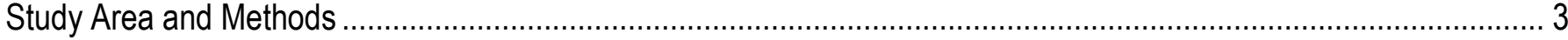

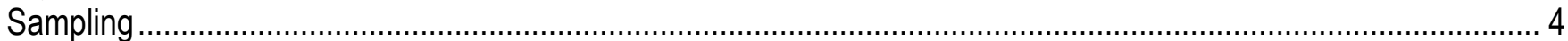

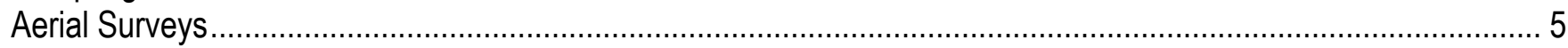

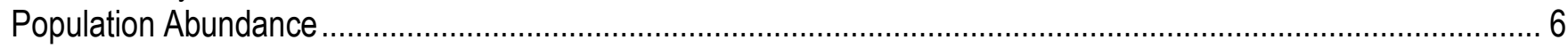

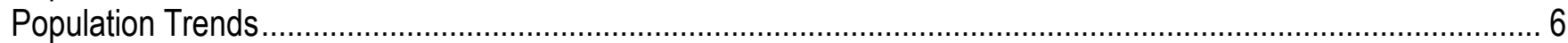

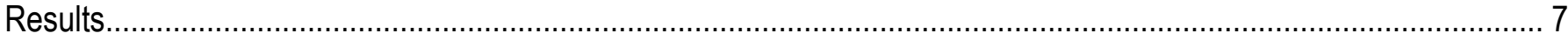

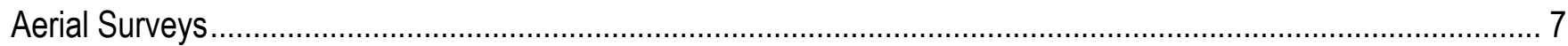

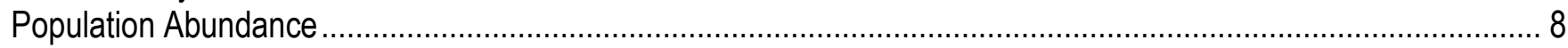

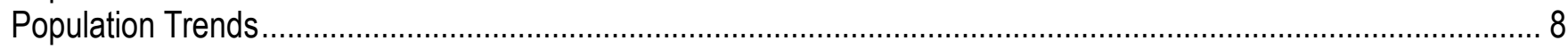

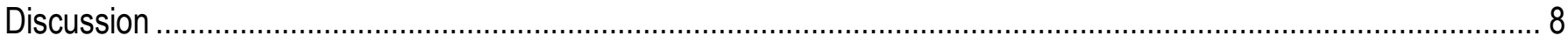

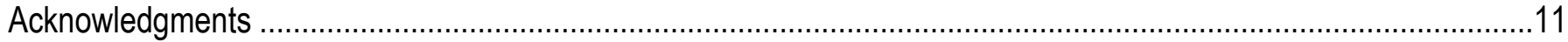

References Cited ................................................................................................................................

Appendix 1. Incidental Observations of Other Wildlife Species by Survey Unit, Olympic Mountains,

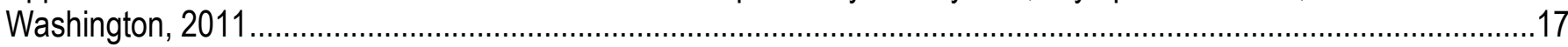

Appendix 2. Trends in Other Wildlife Species Seen during Goat Surveys in the Olympic Mountains,

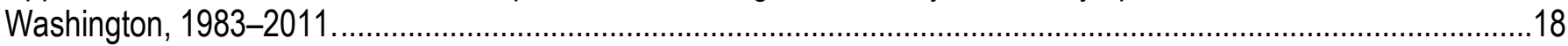

Appendix 3. Survey Flight Characteristics during Aerial Mountain Goat Surveys, Olympic Mountains,

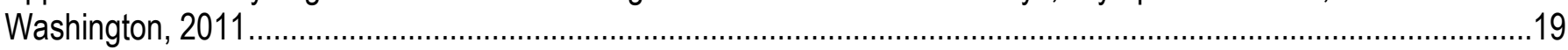

Appendix 4. Survey Characteristics and Environmental Conditions Measured at the Beginning of Each

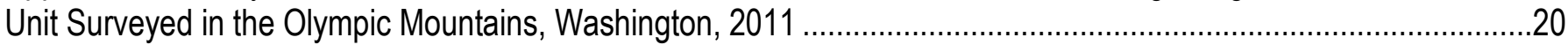

Appendix 5. Raw Counts of Mountain Goats by Survey Unit, Olympic Mountains, Washington, 2011 .......................22

\section{Figures}

Figure 1. Sampling strata, units surveyed, and number of mountain goats counted during mountain goat surveys in the Olympic Mountains, Washington, July 18-25, 2011.

Figure 2. Trends in indices of abundance (solid line) and estimated abundance (dashed line) of mountain goats in the Olympic Mountains survey zone, Washington, 1983-2011.

\section{Tables}

Table 1. Mountain goat survey characteristics and raw counts of mountain goats in the Klahhane Special Management Concern Area, and high, medium, and low density strata, Olympic Mountains, Washington, July 18-25, 2011.

Table 2. Population estimates of mountain goats, associated components of variance, standard errors, and 95-percent confidence intervals in the Olympic Mountains survey zone, Washington, 2004-2011. 


\section{Conversion Factors and Datums}

\section{Conversion Factors}

Inch/Pound to SI

\begin{tabular}{lll}
\hline & Bultiply & Bo obtain \\
\hline foot (ft) & Length & \\
mile (mi) & 0.3048 & meter $(\mathrm{m})$ \\
\hline
\end{tabular}

SI to Inch/Pound

\begin{tabular}{lcl}
\hline \multicolumn{1}{c}{ Multiply } & By & To obtain \\
\hline meter $(\mathrm{m})$ & Length & foot $(\mathrm{ft})$ \\
kilometer $(\mathrm{km})$ & 3.281 & mile $(\mathrm{mi})$ \\
\hline & 0.6214 & \\
\hline hectare $($ ha) & Area & acre \\
square kilometer $\left(\mathrm{km}^{2}\right)$ & 2.471 & square mile $\left(\mathrm{mi}^{2}\right)$ \\
\hline & 0.3861 & \\
\hline kilometer per hour $(\mathrm{km} / \mathrm{h})$ & Flow rate & mile per hour $(\mathrm{mi} / \mathrm{h})$ \\
\hline
\end{tabular}

Temperature in degrees Celsius $\left({ }^{\circ} \mathrm{C}\right)$ may be converted to degrees Fahrenheit $\left({ }^{\circ} \mathrm{F}\right)$ as follows: ${ }^{\circ} \mathrm{F}=\left(1.8 \times^{\circ} \mathrm{C}\right)+32$.

\section{Datums}

Vertical coordinate information is referenced to the North American Vertical Datum of 1988 (NAVD 88). Horizontal coordinate information is referenced to the North American Datum of 1983 (NAD 83).

Elevation, as used in this report, refers to distance above the vertical datum. 


\section{Mountain Goat Abundance and Population Trends in the Olympic Mountains, Washington, 2011}

By Kurt Jenkins, U.S. Geological Survey; Patricia Happe, National Park Service; Paul Griffin, U.S. Geological Survey; and Katherine Beirne, Roger Hoffman, and William Baccus, National Park Service

\section{Executive Summary}

We conducted an aerial helicopter survey between July 18 and July 25, 2011, to estimate abundance and trends of introduced mountain goats (Oreamnos americanus) in the Olympic Mountains. The survey was the first since we developed a sightability correction model in 2008, which provided the means to estimate the number of mountain goats present in the surveyed areas and not seen during the aerial surveys, and to adjust for undercounting biases. Additionally, the count was the first since recent telemetry studies revealed that the previously defined survey zone, which was delineated at lower elevations by the 1,520-meter elevation contour, did not encompass all lands used by mountain goats during summer. We redefined the lower elevation boundary of survey units before conducting the 2011 surveys in an effort to more accurately estimate the entire mountain goat population. We surveyed 39 survey units, comprising 39 percent of the 59,615-hectare survey area. We estimated a mountain goat population of $344+44$ (standard error, SE) in the expanded survey area. Based on this level of estimation uncertainty, the 95-percent confidence interval ranged from 258 to 430 mountain goats at the time of the survey.

To permit comparisons of mountain goat populations between the 2004 and 2011 surveys, we recomputed population estimates derived from the 2004 survey using the newly developed bias correction methods, and we computed the 2004 and 2011 surveys based on comparable survey zone definitions (for example, using the boundaries of the 2004 survey). The recomputed estimates of mountain goat populations were $217 \pm 19$ (SE) in 2004 and $303+41$ (SE) in 2011. The difference between the current 2011 population estimate $(344+44[\mathrm{SE}])$ and the recomputed 2011 estimate $(303 \pm 41$ [SE]) reflects the number of mountain goats counted in the expanded lower elevation portions of the survey zone added in 2011. We conclude that the population of mountain goats has increased in the Olympic Mountains at an average rate of $4.9 \pm 2.2(\mathrm{SE})$ percent annually since 2004 . We caution that the estimated rate of population growth may be conservative if severe spring weather deterred some mountain goats from reaching the high-elevation survey areas during the 2011 surveys. If the estimated average rate of population growth were to remain constant in the future, then the population would double in approximately $14-15$ years. 


\section{Introduction}

Mountain goats were introduced to the Olympic Mountains during the 1920s prior to the establishment of Olympic National Park (Houston and others, 1994). Over the next several decades, the population increased in size and expanded throughout the Olympic Range leading to management concerns by the mid-1970s over the potential impacts of mountain goats on endemic plants, soils, and erosion in subalpine and alpine plant communities (National Park Service, 1995). In 1983, the National Park Service (NPS) conducted the first aerial mountain goat survey in the Olympic Mountains, returning an estimate of 1,175+171 (SE) mountain goats (Houston and others, 1986). During the mid- to late 1980s, the NPS conducted an experimental management program to test the effectiveness and determine logistical requirements of goat removal and transplanting operations as tools to reduce population size (Houston and others, 1991a). From 1981 through 1989, 521 goats were removed from the population; 407 through live capture in the park, 111 through legal hunting outside the park, and 3 known illegal kills within the park (Houston and others, 1994). A second survey in July 1990, conducted following these removals, produced an estimate of 389+106 (SE) goats (Houston and others, 1991b). Subsequent surveys were conducted in 1994, 1997, and 2004 following a period in which no goats were removed by NPS managers, returning estimates of 288+32 (SE), 281 \pm 22 (SE), and 290+17 (SE) goats, respectively (National Park Service, unpublished data, 1994, 1997, 2004). Here we report the results from an additional (sixth) survey conducted during July 2011 and examine recent population trends.

Previous estimates of mountain goats inhabiting the Olympic Mountains were based on aerial helicopter surveys conducted during mid- to late July in a stratified random sample of survey units that collectively encompassed about 50,967 ha of land free of glacial ice above 1,520 m (5,000 ft) elevation (Houston and others, 1986; Happe and others, 2005; note that area estimates varied slightly among previous reports due to refined methods of area estimation over the years). Based on extensive observations made in the 1970s and early 1980s (Stevens, 1979, 1983), the lower elevation boundary of the survey zone was presumed to include the large majority of summer movements and activity of mountain goats (Houston and others, 1986). Raw counts of mountain goats observed by aerial crews were adjusted upwards by a factor of 1.52 to account for mountain goats not detected during the aerial surveys (Houston and others, 1986). This adjustment factor was determined by comparing population estimates derived from the 1980s population removal studies to raw index counts of mountain goats seen from the helicopter (Houston and others, 1986). The sightability adjustment factor determined in this manner accounted for mountain goats that were not detected either because they were outside the survey zone boundaries, or because mountain goats that were present within the survey zone were not seen by aerial survey crews. The approximate magnitude of the adjustment factor has been substantiated by other reports of survey efficiency both locally and regionally (Hoffman, 1987; Johnson, 1983; Gonzalez-Voyer and others, 2001), but using a constant multiplier has been criticized because it does not account for factors that may influence detectability over time, and it underestimates variability of the resulting population estimates (Noss and others, 2000).

Between 2005 and 2008, we placed global-positioning system (GPS) radio-collars on 11 mountain goats in Olympic National Park as part of a comprehensive study of detection bias in helicopter-based surveys of mountain goats in western Washington (Rice and others, 2009; Jenkins and others, 2011). Based on repeated aerial surveys over GPS-collared mountain goats, we developed a sightability model that estimates the probability of detecting any group of mountain goats during an aerial survey as a function of the number of mountain goats present in the group as well as vegetation cover and the presence of terrain obstruction in the immediate area around each group (Rice and others, 2009). This model may be used to adjust the raw counts of mountain goats seen during the survey based on the estimated detection probability of each individual group detected. For example, if the detection 
probability of a single observed group of mountain goats was estimated to be 0.75 , then the number of mountain goats within that group would be multiplied by a correction factor of 1.33 (that is, 1 divided by 0.75 ) to account for goats that were not seen under comparable environmental conditions.

Sightability models have been developed for several ungulate species throughout North America and are widely used to adjust raw counts of animals seen during aerial surveys to more accurately represent actual numbers present (Samuel and others, 1987; Ackerman, 1988; Bodie and others, 1995; Anderson and Lindsey, 1996).

We also documented the summer movements of GPS-collared mountain goats to determine whether the previously defined aerial survey boundaries adequately encompassed the population during summer (Jenkins and others, 2011). Analyses of movements of GPS collared mountain goats revealed that movements of mountain goats to lower elevations outside the prescribed survey zone may have resulted in previous surveys undersampling the population by as much as 30 percent. That potential bias was likely corrected by the 1.52 bias correction term used in previous surveys, but the recently developed models of detection bias do not account for mountain goats outside the surveyed areas. Our studies indicated that surveying to lower elevations in areas around rocky escape terrain would include a greater proportion of the mountain goat population and, coupled with the sightablility model, would produce more accurate population estimates without increasing the survey costs and coverage appreciably (Jenkins and others, 2011).

Hence, we made two important changes to the aerial survey protocol in 2011 to more accurately estimate the mountain goat population. First, we adjusted the survey boundaries to include a greater proportion of the summer range used by mountain goats. Second, we adjusted aerial survey counts to account for detection biases using the sightability model (Rice and others, 2009). Here we report the estimated number of mountain goats inhabiting the Olympic Mountains and determine population trends between 2004 and 2011.

\section{Study Area and Methods}

The Olympic Mountains are noted for steep gradients in elevation, vegetation, and precipitation within a context of highly convoluted topography and landforms (Tabor, 1987; Henderson and others, 1989). The Olympic Mountains rise abruptly from the coastal plains and foothills, culminating in Mount Olympus, the highest peak at 2,430 m elevation, and 37 other major peaks exceeding 2,130 m elevation, all within about $50 \mathrm{~km}$ of the sea (Houston and others, 1994). Eleven major watersheds drain radially from the Olympic Mountains to the Pacific Ocean to the west, Strait of Juan de Fuca to the north, and Hood Canal to the east. Moist Pacific storms, generally arriving from the southwest and intercepted by the Olympic Range, result in steep gradients in precipitation. Precipitation increases with elevation along the southern and western slopes of the Olympic Mountains, reaches a peak in the interior mountains, and decreases sharply in the leeward northeastern Olympics. Winter precipitation falls primarily as rain in lowlands below about $300-500 \mathrm{~m}$, as rain and snow at intermediate elevations, and primarily as snow above $1,000 \mathrm{~m}$ elevation.

As in all previous surveys of mountain goats in the Olympic Mountains, we surveyed during mid- to late July to target the seasonal window after mountain goats have moved to higher elevations for summer (Rice, 2008; Jenkins and others, 2011) but before hot mid-summer temperatures present operational difficulties for flying at high elevations. Abnormally heavy snowfall, unseasonably cool spring weather, and late snowpack persisted during the 2011 survey. The snowpack was about 160 percent of normal on April 1 and 200 percent of normal on May 1 based on a 60-year record for two high-elevation snow surveys conducted annually in the Olympic Mountains (National Park Service, unpublished data, 2011). The SNOTEL monitoring station at Hurricane Ridge in the northern Olympic 
Mountains (1,524 m) generally becomes snow free between July 10 and July 15 (based on a 10-year record), but snow persisted until July 24, 2011 (National Park Service, unpublished data, 2011). Although steep terrain was largely free of snow during the surveys, particularly on southern aspects and in the drier northeast, shaded areas such as north- and east-facing cirques, bowls, and forested areas were still snow covered throughout much of the survey area.

\section{Sampling}

We made two adjustments to the sampling frame for the 2011 survey. First, we omitted the Mount Washington sampling unit (Olympic National Forest, southeastern Olympic Peninsula) from the survey due to logistical difficulties and funding limitations. Second, we added lower elevations in areas of suitable habitat to the previously defined survey units that were used from 1983 through 2007. Additional suitable habitat was identified as land between 1,425 and 1,520 m elevations where escape terrain comprised at least 50 percent of the elevation band. We defined escape terrain as area less than $111 \mathrm{~m}$ from any $25 \times 25-\mathrm{m}(0.0625 \mathrm{ha})$ raster cell classified as rock (Olympic National Park vegetation cover map, Pacific Meridian Resources, 1996) and with slope greater than 33 percent. We chose the 111-m threshold because 90 percent of all locations of GPS-collared mountain goats were less than 111 $\mathrm{m}$ from escape cover when they were lower than $1,520 \mathrm{~m}$ in elevation during the July sampling window. The 50-percent classification was a subjective decision that reflected costs and logistical considerations to minimize survey effort over relatively large areas of low-quality and unused habitats.

As in past surveys, we used stratified random sampling procedures to select sampling units for aerial surveys. Due to the addition of lower elevations to the previously defined survey units, we occasionally redefined unit boundaries in an effort to maintain consistency in survey unit sizes at about 500 ha. If a unit was split, the new name retained the original number (for example, 127 was split into $127 \mathrm{~N}$ and $127 \mathrm{~S}$ ) for ease of comparisons across survey years. If a wholly new survey area was added to accommodate the new acreage additions, we assigned a new survey unit number. The expanded survey zone comprised a total of 108 sampling units covering 59,615 ha. The addition of lower elevation habitats in 2011 increased the survey zone by 18 percent over the area included in the sampling frame used for previous surveys, which was 50,567 ha excluding the Mount Washington Unit.

As in years past, we assigned each of the survey units to one of four survey strata prior to the surveys. These included areas of special management concern, low-density, medium-density, and highdensity strata. Stratum assignments for each survey unit were based on the results of past mountain goat surveys and recent observations reported by park staff.

a) Areas of special management concern: The only unit in this category in 2011 was the area designated in previous surveys as the Klahhane Ridge Total Count Unit. We maintained Klahhane Ridge in this category for continuity with previous surveys, and because it was the site of intensive population manipulation and study during the 1970-90s and it remains an area of management concern today. The Klahhane Ridge unit comprised 2,041 ha.

b) Known or suspected high-density areas: Units were assigned to this stratum if we expected to find 10 or more mountain goats per 500 ha based on previous surveys and field observations. Between 2004 and 2011, numbers of goats reported by visitors and park staff increased. Based on that information, we increased the number of suspected high-density areas from four survey units comprising 3,547 ha in 2004 to 10 units covering 7,606 ha in 2011 . We surveyed all units in the high density stratum. 
c) Known or suspected medium-density areas: Units were assigned to this stratum if we expected 1-9 mountain goats per 500 ha inhabiting the survey unit. The medium-density stratum comprised 20,599 ha in 41 survey units ranging in size from 220 to 712 ha. We randomly selected 22 survey units (54 percent) in the sample.

d) Known or suspected low-density areas: Units were assigned to this stratum if we expected no mountain goats. The low-density stratum comprised 29,369 ha in 56 survey units ranging in size from 363 to 659 ha. Six survey units (11 percent) were randomly selected in the sample.

After allotting survey time for all high-density units and Klahhane Ridge, we allocated the remaining survey effort among low- and medium-density strata using standard optimal allocation methods (Cochrane, 1977) based on sampling variances reported in 2004 (Happe and others, 2005).

\section{Aerial Surveys}

Aerial survey procedures were similar to those used in previous surveys (Houston and others, 1986, 1991b; Happe and others, 2005; Rice and others, 2009). Most surveys were conducted between dawn and about 10:30 a.m. by a pilot and three-person crew aboard an MD-500D helicopter. The pilot's primary responsibility was to safely fly the aircraft but the pilot also reported observations. We counted mountain goats within the selected survey units by flying multiple contours about $100 \mathrm{~m}$ from the terrain (that is, above flat terrain or horizontally away from vertical terrain) at elevations spaced 90-150 $\mathrm{m}$ apart vertically. Flight speed was maintained between 56 and $72 \mathrm{~km} / \mathrm{h}(35-45 \mathrm{mi} / \mathrm{h})$. Lower elevations of each unit were flown first and then the helicopter progressively worked upslope until the entire unit was searched. We used a GPS unit aboard the helicopter during all surveys to assist with navigation, map flight paths, and record the approximate locations of goat groups and other wildlife seen during the surveys.

We recorded conditions related to each helicopter flight, survey unit, and group of mountain goats observed. For each flight, we recorded crew members' names and various flight descriptors (times and locations of takeoffs and landings). We recorded times at the start and end of each unit surveyed and several environmental conditions, including cloud cover, wind strength, precipitation level, and temperature. Upon spotting a group of mountain goats, observers recorded the total number of mountain goats, number of young of the year (kids), and the following covariates: activity of most animals when first sighted (bedded, standing, or moving), substrate for most animals when first sighted (rock, snow, herbaceous vegetation, or forest), the percentage of vegetation obstruction cover capable of obscuring a mountain goat within a 10-m buffer around the group (0, 1-25, 26-50, 51-75, 76-100), and whether terrain obstruction was present within a $10-\mathrm{m}$ buffer around the group at the moment it was first seen. We defined terrain obstruction as any landform capable of obscuring a mountain goat from the air. The group size, vegetation, and terrain obstruction covariates were used to estimate group specific detection probabilities for bias correction (Rice and others, 2009).

We also recorded whether each observed group was in the newly added area at lower elevations within each survey unit (that is, between 1,425 and 1,520 m elevations) and whether the group was below, level with, or above the helicopter flight line. These last two pieces of information were recorded to compare mountain goat abundance in 2011 to previous estimates made within the more restricted survey area. Lastly, we recorded sightings of other wildlife observed incidental to the survey. These incidental observations are summarized in appendixes 1 and 2 and are not discussed further here. 


\section{Population Abundance}

We estimated mountain goat abundance using the sightability modeling approach developed by Steinhorst and Samuel (1989). This approach combines counts of animals, or groups of animals, in a set of randomly sampled survey units with a model for their probability of detection. For a stratified random sample of survey units, the estimate of population size $(\hat{\tau})$ is given by:

$$
\hat{\tau}=\sum \sum \sum\left(\frac{N_{h}}{n_{h}} \hat{\theta}_{h, i, j} Y_{h, i, j}\right)
$$

where the sums are over strata $(h)$, sampled survey units $(i)$, and observed groups $(j) ; n_{h}$ and $N_{h}$ are, respectively, the number of stratum $h$ plots in the sample and in the population; the $\hat{\theta}$ 's are estimated sightability correction factors associated with each observed group ( $\sim$ the inverse of each group's detection probability); and $Y_{h, i, j}$ gives the number of animals in the $j^{\text {th }}$ observed group (within the $i^{\text {th }}$ survey unit in stratum $h$ ).

We estimated sightability correction factors for each observed group using model-averaged regression coefficients and their unconditional variance covariance matrix from Rice and others (2009) along with formulas from Steinhorst and Samuel (1989). Specifically, Rice and others (2009) used sighting data from 205 sightability trials to model the probability of detection for each mountain goat group $(j), p_{\text {detect }, j}$, as a function of group size (Group $\left.\operatorname{Size}_{j}\right)$, percent vegetative obstruction $\left(\% \mathrm{Veg}_{j}\right)$, and terrain obstruction $\left(\right.$ Terrain $\left._{j}\right)$.

$$
p_{\text {detect }, j}=\frac{e^{\left(\beta_{1}+\beta_{2} * \text { GroupSize }, j+\beta_{3} * \text { Terrain }, j+\beta_{4} * \text { Veg }, j\right)}}{1+e^{\left(\beta_{1}+\beta_{2} * \text { GroupSize } j+\beta_{3} * \text { Terrain }, j+\beta_{4} * \% \text { Veg }, j\right)}}=\frac{e^{\left(x_{j}^{\prime} \boldsymbol{\beta}\right)}}{1+e^{\left(x_{j}^{\prime} \boldsymbol{\beta}\right)}}
$$

The estimated regression coefficients ( $\hat{\beta}$; Rice and others, 2009, p. 474) and their estimated unconditional variance/covariance matrix, $\widehat{\Sigma}$ (Rice and others, 2009, p. 474), were then used to estimate the sightability correction factors using the following equation from Steinhorst and Samuel (1989):

$$
\widehat{\theta}_{h, i, j}=1+e^{\left(-x_{j}^{\prime} \widehat{\boldsymbol{\beta}}-\frac{x_{j} \hat{\Sigma} x_{j}{ }^{\prime}}{2}\right)}
$$

Three random processes create uncertainty in the estimated abundance $(\hat{\tau}):(1)$ the random sampling of survey plots; (2) random detection (and failed detection) of independent groups within surveyed plots; and (3) variation in estimation of parameters used to model sightability. Wong (1996) developed consistent (asymptotically unbiased) estimators of each of these variance components. We used a script (Sightability.Model) for Program R (R Development Core Team, 2011) developed by John Fieberg (Minnesota Department of Natural Resources, Forest Lake, Minnesota), to estimate total abundance using the Steinhorst and Samuel (1989) estimator (eq.1), and $\operatorname{Var}(\hat{\tau})$ using equations from Wong (1996).

\section{Population Trends}

It was not possible to determine population trends directly from surveys conducted from 1983 to 2011 because of changes made to the sampling area in 2011 as well as changes to methods used to estimate detection biases. However, because we collected covariate data associated with mountain goat observations in 2004, we adjusted the 2004 data for detection biases using the sightability model and compared population estimates and determined the rate of population growth between 2004 and 2011. 
To place the 2004 and 2011 population estimates in historical context, we computed population indices from all counts conducted from 1983 to 2011. Population indices were the estimated counts of mountain goats throughout the Olympic Mountains prior to any adjustments to account for detection biases. These population indices were computed using stratified random sampling computational methods described by Norton-Griffiths (1978) and used by Houston and others (1986, 1991b). Consequently, these indices are minimum population estimates because they do not account for animals present but not seen during surveys. Moreover, the comparison of population indices over time assumes that sightability of mountain goats did not change over time.

To compare the 2004 and 2011 population estimates and the 1983 to 2011 index values, it was necessary to ensure that comparisons were based on the same surveyed areas. We made the following adjustments to account for differences in survey boundaries among years: (1) all observations of mountain goats from the new survey areas added in 2011 were removed from the 2011 dataset (that is, observations between 1,425 and 1,520 m elevations), (2) observations from the Mount Washington Unit, which was not surveyed in 2011, were removed from the 1983-2004 datasets. Hence, abundance estimates and indices reflect numbers of mountain goats in lands free of permanent snow and ice above 1,520 m elevation and excluding the Mount Washington Unit in the Olympic National Forest (fig. 1).

We used a 2-tailed $z$-test to determine whether or not two estimates of abundance differed statistically from a null hypothesis of zero change (Thompson and others, 1998). We also estimated both the instantaneous rate of exponential population growth and the average finite rate of growth necessary to cause the observed changes in estimated abundance from 2004 to 2011, based on the difference of the log-transformed abundance estimates (Caughley, 1977, p. 51). Because we used the same sightability model to estimate abundance of mountain goats in 2004 and 2011, we used the Sightability. Model script in program $\mathrm{R}$, which takes into account the covariance between years, and to estimate variance of the population growth rate (R Development Core Team, 2011; available from J. Fieberg, Minnesota Department of Natural Resources, Forest Lake, Minnesota).

\section{Results}

\section{Aerial Surveys}

We conducted aerial surveys during six mornings from July 18 to July 25, 2011. We surveyed mountain goats within 39 survey units totaling 23,458 ha (table 1). This is similar to the amount of area surveyed in 2004 (that is, 41 survey units comprising 24,524 ha in 2004; Happe and others, 2005). Although the total area surveyed was comparable in 2004 and 2011, because we expanded the total survey zone to include lower elevations in 2011, we sampled a lower proportion of the total survey zone in 2011 (39 percent) than in 2004 (48 percent). Total flight time, including travel between survey units and fueling locations, was 27.1 hours in 2011 . Of that, we actively searched for mountain goats within survey units for 18.4 hours $(1,106 \mathrm{~min}$, table 1$)$. This is slightly less efficient than in 2004 , when flight time was 25.8 hours including 18 hours on survey.

Survey intensity averaged $4.7 \mathrm{~min} / \mathrm{km}^{2}$ across all surveyed units, ranging from 3.7 to 5.3 $\mathrm{min} / \mathrm{km}^{2}$ in the low and high-density strata, respectively (table 1). Differences in survey intensity among survey units and strata reflected variation in habitat complexity and the time required to count mountain goats and record observations, rather than any variation in our expectation of finding goats. Detailed summaries of all individual flights and survey conditions are provided in appendixes 3 and 4, respectively. 


\section{Population Abundance}

We counted a total of 217 mountain goats in the four strata (table 1, fig. 1). The estimated population of mountain goats within the Olympic Mountains survey zone (all estimates exclude Mount Washington) corrected for detection bias was $344 \pm 44(\mathrm{SE})$ at the time of the survey (table 2). The total variance of the population estimate, $\operatorname{Var}(\hat{\tau})$, was 1,924 , which accounts for variance associated with random sampling of survey units ( $\operatorname{Var}_{\text {sampling }}=1,212$ or 63 percent of the total), random detections of independent groups ( $\operatorname{Var}_{\text {detection }}=432$ or 22 percent of total), and uncertainty in model estimation ( Var $_{\text {model }}=280$ or 15 percent of total). The 95-percent confidence interval, defined as the estimate $\pm 1.96(\mathrm{SE})$, ranged from 258 to 430 mountain goats.

\section{Population Trends}

Population estimates corrected for detection biases and adjusted for comparable survey areas were $217 \pm 19$ (SE) mountain goats in 2004 and 303 +41 (SE) mountain goats in 2011 (table 2, fig. 2). Compared with the abundance estimate of 344 mountain goats for the expanded survey zone used in 2011, the estimate of 303 mountain goats presented here pertains to the more restricted survey zone defined in previous years (that is, areas above $1,520 \mathrm{~m}$ elevation). The estimated population in the expanded survey zone was approximately 14 percent greater than in the original survey area, reflecting mountain goats observed in the newly added area between 1,425 and 1,520 m elevations during the 2011 surveys.

Based on population estimates of mountain goats within the comparable survey zone, mountain goat abundance was greater in 2011 than in $2004(z=2.04, P=0.04)$. The $z$-statistic indicated that a difference in population estimates of this magnitude (or greater) would only occur 4 percent of the time if the null hypothesis of equal population size was true. The estimated population of mountain goats increased at an instantaneous rate $(r)$ of $0.048+0.021$ (SE) between 2004 and 2011, representing a 4.9 percent finite rate of population increase annually (that is, $\lambda=1.049 \pm 0.022[\mathrm{SE}]$ ).

Minimum population indices of mountain goats in the Olympic Mountains survey zone, excluding Mount Washington area, ranged from a high of $755 \pm 116(\mathrm{SE})$ in 1983 , to lows of $171 \pm 15(\mathrm{SE})$ in 1997 and 179 $+10(\mathrm{SE})$ in 2004 following the experimental removals. The population index increased to $232 \pm 27$ (SE) in 2011 (fig. 2).

\section{Discussion}

After a relatively long period of population stability following the experimental population reductions in the 1980s, the mountain goat population increased in the Olympic Mountains survey zone between 2004 and 2011. The reasons for the long period of population stability and the relatively slow rate of population growth from 1994 to 2004 are poorly understood. Mountain goats are sensitive to high rates of removal, such as those implemented during the experimental reductions in the 1980s, due to their relatively low rate of reproduction and the combined additive effects of natural and humancaused mortality or other removals (Côté and Festa-Bianchet, 2003; Hamel and others, 2006). Population recovery from over harvest or culling appears to be highly individualized among different populations, but is hindered most in small populations that may be more susceptible to stochastic events such as density-independent mortality (Hamel and others, 2006; Rice and Gay, 2010). Recent genetic studies, which revealed low allelic diversity and evidence of inbreeding in the Olympic Mountains, suggest that genetic factors also played a role in the slow return of mountain goats to the Olympics, as throughout parts of the Cascades (Shirk, 2009). The interaction between population performance and genetics of mountain goats in Washington remains speculative, but survival rates of sub-adult mountain 
goats has been shown to be affected negatively by low genetic diversity in Alberta (Mainguy and others, 2009). Reasons for the recent upturn in the number of mountain goats in the Olympics also remain poorly understood.

Despite efforts to survey a more complete segment of the total population and adjust for detection biases in 2011, the resulting population estimate still must be considered a minimum estimate. We estimated about 14 percent more mountain goats by expanding the survey zone by 18 percent to include escape terrain at comparatively low elevations in 2011. Because GPS-collared mountain goats have been observed using elevations less than 1,400 m elevation (Jenkins and others, 2011), the expanded survey boundaries are unlikely to include the entire population. We have no means to estimate the effects of the unseasonably late and deep snows on mountain goat distribution patterns and detectability in 2011, but we suspect the near-record late and persistent snows may have reduced mountain goat use of some survey units. We received one report of mountain goats seen by NPS staff at low elevations outside the survey zone during our surveys. Furthermore, we counted no mountain goats in one survey unit where mountain goats have been common in recent years, and where mountain goats appeared after surveys were completed. Our previous studies did not reveal an effect of snow on aerial detectability of mountain goats (Rice and others, 2009), but snow depths and cover were greater during 2011 than during the years of model development. The effects of extensive snow cover on goat sightability and distribution is not known. Hence, we caution that our population estimate is conservative, reflecting only the number of goats present in areas of acceptable escape terrain greater than 1,425 m elevation at the time of the 2011 survey. If the combination of weather and goat behavior led us to underestimate the actual population size in 2011, it also would lead to underestimating the actual population differences and the rate of population growth estimated between 2004 and 2011.

Modifications made to survey design and methodology in 2011 increased the accuracy of mountain goat population estimates. We estimated 44 percent more goats in 2011 by adjusting survey boundaries to lower elevations in areas of suitable habitat and by correcting for sightability biases. We derived this percentage based on comparing the bias-corrected population estimate in 2011 $(344+44[\mathrm{SE}])$ to the unadjusted index count of mountain goats within the survey boundaries used in previous surveys (that is, above 1,520 m elevation; 239 $\pm 26[\mathrm{SE}]$ ). These numbers return a correction ratio of 1.44, which is similar to the ratio of 1.52 used in earlier surveys (Houston and others, 1986, 1991b). If deep snows caused us to underestimate the population of mountain goats in 2011 , then we may have underestimated the true detection bias in 2011 and average correction factors derived from the past and present methods may be even more similar than indicated. The similarity of detection biases estimated here to those applied in past surveys supports the contention that the historically adjusted numbers were more representative of actual populations than were indices based on raw counts alone (Houston and others, 1986, 1991b).

Using the sightability model rather than a constant ratio estimator of detection bias allowed us to capture more sources of uncertainty in 2011 than in past years. Variances, standard errors, and confidence intervals - all measures of uncertainty in the population estimates - were greater during 2011 than in 2004 (table 2, fig. 2). Estimated precision reflected annual differences in sampling variation and estimation methods, which in 2011 included methods to estimate variance associated with random detection and model estimation, not just sampling variability (Steinhorst and Samuel, 1989; Wong, 1996). Sampling variability contributed 63 percent of the total variance in 2011 population estimates but only 37 percent of total variance in 2004 . These trends indicate that sampling variability was higher in 2011 than 2004, but also that previous surveys underestimated the total variance by not accounting for uncertainties associated with random detection and sightability modeling. 
Greater sampling variation in 2011 was related to several factors. First, high counts of goats were unexpected in three counting units in the moderate-density stratum in 2011 (11-15 goats, fig. 1), which increased sampling variation. Second, because we expanded the survey area in 2011 and increased sampling efforts in the high-density stratum, we surveyed a smaller proportion of the total survey area in 2011 (39 percent) than in 2004 (48 percent), and an even lower relative proportion of the variable moderate-density stratum (52 versus 84 percent, respectively). We were not able to achieve the same sampling intensity in 2011 as in 2004 because we operated on a fixed budget while surveying a larger area in 2011.

Measures to increase survey accuracy and precision would improve the ability of managers to detect population trends and manage mountain goat populations most effectively in the future. Although we have invested heavily to obtain a more accurate method of population estimation, the influence of unseasonable weather on mountain goat distribution remains a potential source of inaccuracy. In years of uncharacteristic late season and deep summer snow, postponing surveys until September or another year may help to ensure that all mountain goats are present at high elevations during the survey and the entire population is estimated accurately.

Changes in logistics and survey design also may increase precision of future surveys. Precision of population estimates is determined by overall survey effort as well as variability of counts within sampling strata. Survey effort, defined as the total area surveyed, is controlled most directly through funding level, but also could be increased by improving survey efficiency (that is, surveying more area on the same budget). Survey flight speeds are defined by the sightability model protocol and have been constant since the early 1980s, so increasing flight speed or adjusting survey coverage are not viable options for increasing survey efficiency. Efficiency may be increased, however, by fueling out of more centrally located staging areas than used in 2011. In 2011, we fueled out of Deer Park in the northeastern Olympics due to deep snows that prevented fueling at Obstruction Point, a more centrally located fueling and staging area. A return to using Obstruction Point should reduce travel times associated with refueling and increase overall survey efficiency during years of less snow.

The history of mountain goat surveys in the Olympic Mountains demonstrates the inherent variability of these surveys, and the difficulty of reducing sampling variability. Unexpected high counts of goats outside the predicted stratum bounds have been a recurring issue (Houston and others, 1986, 1991b), likely due to the clumped distribution and wide movements of goats relative to sampling units. It seems unlikely that we will be more successful in the future in reducing within-strata sampling variability, particularly in a period of increasing populations. Hence, with more area to survey and the population increasing, more funding than was used in 2011 would be needed to achieve greater precision in future surveys. Because sampling variability is determined by unit-to-unit variability in estimated numbers of goats, it may be beneficial to stratify based on expected numbers of goats within survey units rather than density. Additionally, increasing the relative sampling allocation to the variable moderate-density stratum may reduce sampling variation and enhance the precision of future surveys.

Although current evidence points to an increasing population of mountain goats in the Olympics, uncertain effects of climate and genetic factors obscure future trends. If the estimated average rate of population growth were to remain constant, however, the population would increase by 50 percent in the next 8-9 years and would double in 14-15 years. Now that the population has begun to increase following control measures of the 1980s and a period of relative stability in the $1990 \mathrm{~s}$, more frequent surveys may be warranted to better inform mountain goat planning and management activities in the future. 


\section{Acknowledgments}

This study was funded principally by the National Park Service Natural Resources Preservation Program Regional Block Grant through an interagency agreement to the USGS Forest and Rangeland Ecosystem Science Center. Additional funding was provided by Olympic National Park. We would like to thank Larry Nickey, Todd Rankin, Corky McKeown, Stephanie Frey, and the staffs at the Emergency Operations Center and Dispatch Office at Olympic National Park for their help in aviation planning and communications during the surveys. We are grateful to Trever Walker (Northwest Helicopters) for safely piloting all surveys. John Fieberg, Minnesota Department of Natural Resources, graciously shared software applications and consulted with us on computational methods. John Fieberg, Doug Houston, and Cliff Rice provided very helpful reviews of this manuscript. We are grateful for the assistance of Ruth Jacobs, Shirley Koetz, and Linda Rogers in preparing this publication.

\section{References Cited}

Ackerman, B.B., 1988, Visibility bias of mule deer aerial census procedures in southeast Idaho: Moscow, Idaho, University of Idaho, Ph.D. dissertation.

Anderson, C.R., Jr., and Lindsey, F.G., 1996, Moose sightability model developed from helicopter surveys: Wildlife Society Bulletin, v. 24, p. 247-259.

Bodie, W.L., Garton, E.O., Taylor, E.R., and McCoy, M., 1995, A sightabity model for bighorn sheep in canyon habitats, Journal of Wildlife Management, v. 59, p. 832-840.

Cochran, W.G., 1977, Sampling techniques: New York, NY., John Wiley and Sons.

Côté, S.D., and Festa-Bianchet, M., 2003, Mountain goat., in Feldhamer, G.A., Thompson, B.C., and Chapman, J.A., eds., Wild mammals of North America: Biology, management, and conservation, Second edition: Baltimore, Md., Johns Hopkins University Press, p. 1061-1075.

Caughley, G., 1977, Analysis of vertebrate populations: London, John Wiley and Sons.

Gonzalez-Voyer, A., Festa-Bianchet, M., and Smith, K.G., 2001, Efficiency of aerial surveys of mountain goats: Wildlife Society Bulletin, v. 29, p. 140-144.

Hamel, S., Côté, S.D., Smith, K.G., and Festa-Bianchet, M., 2006, Population dynamics and harvest potential of mountain goat herds in Alberta: Journal of Wildlife Management, v. 70, p. 1044-1053.

Happe, P. J., Jenkins, K.J., Beirne, K.F., Albright, J.W., Baccus, W.T., and Olson, R.W., 2005, Mountain goat census in the Olympic Mountain Range, July 2004: Port Angeles, Wash., National Park Service, Olympic National Park.

Henderson, J.A., Peter, D.H., Lesher, R.D., and Shaw, D.C., 1989, Forested plant associations of the Olympic National Forest: U.S. Department of Agriculture, Forest Service, Pacific Northwest Region R6 Ecological Technical Paper 001-88.

Hoffman, R.A., 1987, A comparison of population control techniques for mountain goats in Olympic National Park using field sterilization procedures and computer modeling: Moscow, Idaho, University of Idaho, M.S. Thesis.

Houston, D.B., Moorhead, B.B., and Olson, R.W., 1986, An aerial census of mountain goats in the Olympic Mountain Range, Washington: Northwest Science, v. 60, p. 131-136.

Houston, D.B., Moorhead, B.B., and Olson, R.W., 1991b, Mountain goat population trends in the Olympic Mountain Range, Washington: Northwest Science, v. 65, p. 212-216.

Houston, D.B., Schreiner, E.G., Moorhead, B.B., and Olson, R.W., 1991a, Mountain goat management in Olympic National Park: a progress report: Natural Areas Journal, v. 11, p. 87-92. 
Houston, D.B., Schreiner, E.G., and Moorhead, B.B., eds., 1994, Mountain goats in Olympic National Park: Biology and management of an introduced species: U.S. Department of the Interior, National Park Service, Scientific Monograph NPS/NROLYM/NRSM-94/25.

Jenkins, K., Beirne, K., Happe, P., Hoffman, R., Rice, C., and Schaberl, J., 2011, Seasonal distribution and aerial surveys of mountain goats in Mount Rainier, North Cascades, and Olympic National Parks, Washington: U.S. Geological Survey Open-File Report 2011-1107, 56 p. (Also available at http://pubs.usgs.gov/of/2011/1107/.)

Johnson, R.L., 1983, Mountain goats and mountain sheep of Washington: Washington State Game Department, Olympia, Wash., Biological Bulletin, No. 18.

Mainguy, J., Côté, S.D., and Coltman, D.W., 2009, Multilocus heterozygosity, parental relatedness and individual fitness components in a wild mountain goat, Oreamnos americanus, population: Molecular Ecology v. 18, p. 2297-2306.

National Park Service, 1995, Goats in Olympic National Park: Draft environmental impact statement for goat management: Port Angeles, Wash., Olympic National Park.

Norton-Griffiths, M., 1978, Counting Animals: African Wildlife Leadership Foundation, Serengeti Ecological Monitoring Programme, Nairobi, Kenya, Handbook No. 1.

Noss, R.F., Graham, R., McCullough, D.R., Ramsey, F.L., Seavey, J., Whitlock, C., and Williams, M.P., 2000, Review of scientific material relevant to the occurrence, ecosystem role, and tested management options for mountain goats in Olympic National Park: Corvallis, Oreg., Conservation Biology Institute.

Pacific Meridian Resources, 1996, Vegetation and landform database development study: final report. Portland, Oreg., Pacific Meridian Resources.

R Development Core Team, 2011, R: A language and environment for statistical computing: Vienna, Austria, R. Foundation for Statistical Computing, accessed November 21, 2011, at http://www.Rproject.org/.

Rice, C.G., 2008, Seasonal altitudinal movements of mountain goats: Journal of Wildlife Management, V. 72, p. 1706-1716.

Rice, C.G., Jenkins, K.J., and Chang, W.Y., 2009, A sightability model for mountain goats: Journal of Wildlife Management, v. 73, p. 468-478.

Rice, C.G., and Gay, D., 2010, Effects of mountain goat harvest on historic and contemporary populations: Northwestern Naturalist, v. 91, p. 40-57.

Samuel, M.D., Garton, E.O., Schlegel, M.W., and Carson, R.G., 1987, Visibility bias during aerial surveys of elk in north-central Idaho: Journal of Wildlife Management, v. 51, p. 622-630.

Shirk, A.J., 2009, Mountain goat genetic structure, molecular diversity, and gene flow in the Cascade Range, Washington: Bellingham, Wash., Western Washington University, M.S. thesis.

Steinhorst, K.R., and Samuel, M.D., 1989, Sightability adjustment methods for aerial surveys of wildlife populations: Biometrics. v. 45, p. 415-425.

Stevens, V., 1979, Mountain goat (Oreamnos americanus) habitat utilization in Olympic National Park: Seattle, Wash., University of Washington, M.S. thesis.

Stevens, V., 1983, The dynamics of dispersal in an introduced mountain goat population: Seattle, Wash., University of Washington, Ph.D. dissertation.

Tabor, R.W., 1987, Guide to the geology of Olympic National Park: Pacific Northwest Parks and Forest Association, Seattle, Washington, 144 p.

Thompson, W.L., White, G.C., and Gowan, C., 1998, Monitoring vertebrate populations: San Diego, California, Academic Press.

Wong, C., 1996, Population size estimation using the modified Horvitz-Thompson estimator with estimated sighting probabilities: Fort Collins, Colo., Colorado State University, Ph.D. dissertation. 


\section{Figures}

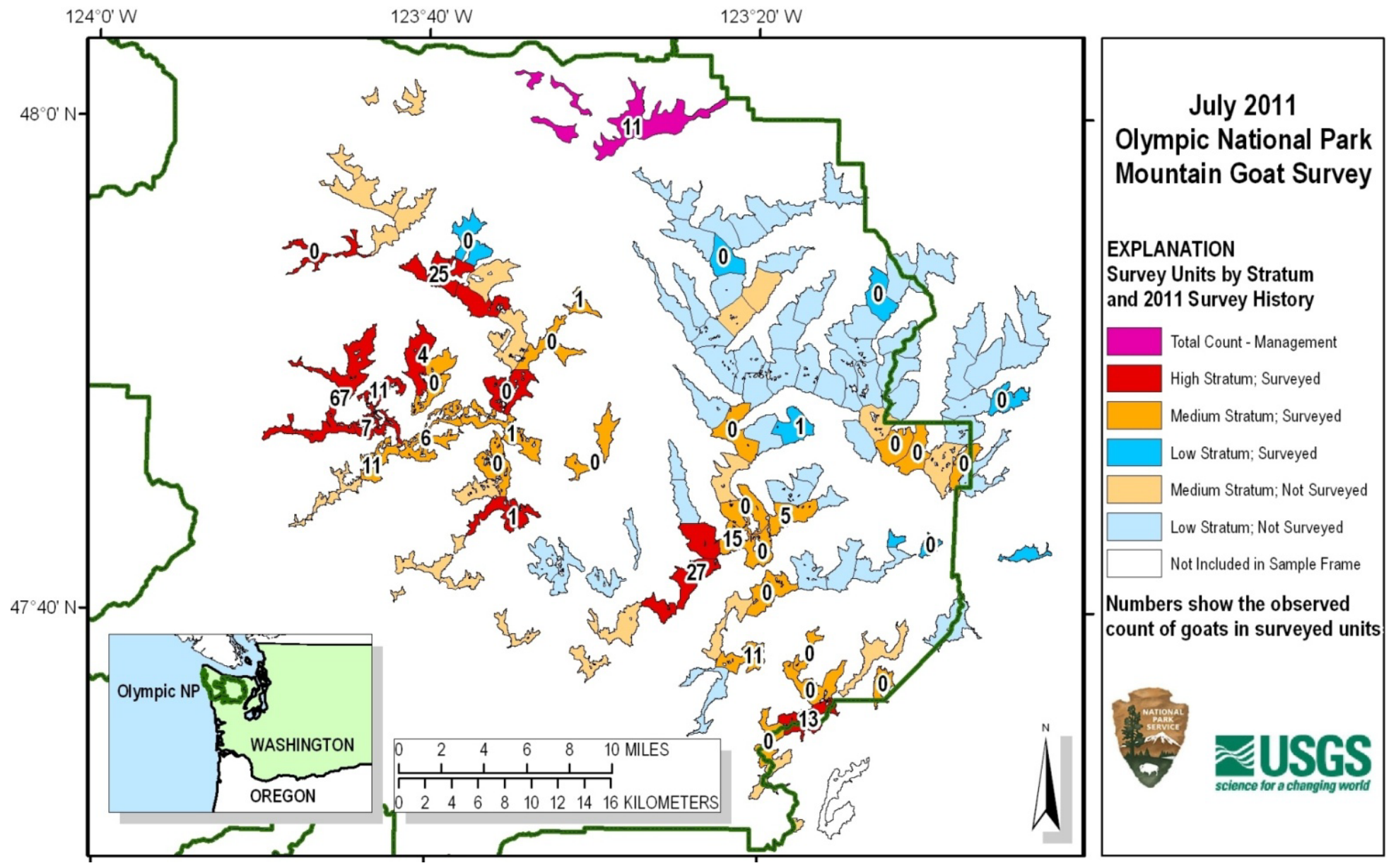

Figure 1. Sampling strata, units surveyed, and number of mountain goats counted during mountain goat surveys in the Olympic Mountains, Washington, July 18-25, 2011. Raw total counts and number of kids (young of the year) are presented in appendix 5. 


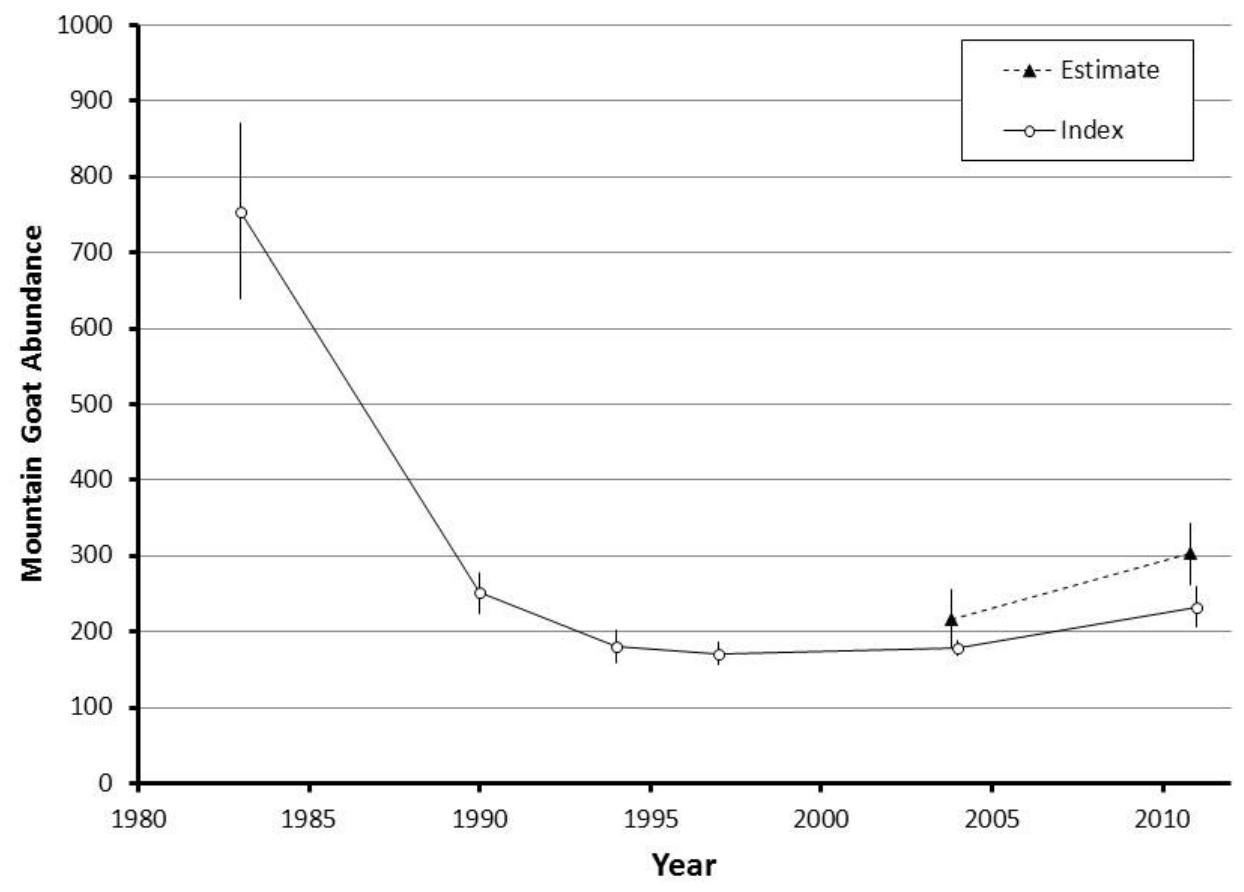

Figure 2. Trends in indices of abundance (solid line) and estimated abundance (dashed line) of mountain goats in the Olympic Mountains survey zone, Washington, 1983-2011. The solid black line connects point estimates of the minimum population indices (+SE), excluding the Mount Washington survey unit. The dashed line connects the 2004 and 2011 sightability-adjusted estimated abundance of mountain goats, excluding the Mount Washington survey unit. Standard errors of the minimum population indices account for sampling variability only, whereas standard errors of the population estimates account for sampling variation, random detection, and sightability model estimation. 


\section{Tables}

Table 1. Mountain goat survey characteristics and raw counts of mountain goats in the Klahhane Special Management Concern Area, and high, medium, and low density strata, Olympic Mountains, Washington, July 18-25, 2011.

[ha, hectares; min, minutes; $\min / \mathrm{km}^{2}$, minutes per square kilometer]

\begin{tabular}{lcccccccc}
\hline \multicolumn{1}{c}{ Stratum } & Area (ha) & $\begin{array}{c}\text { Number } \\
\text { of units }\end{array}$ & $\begin{array}{c}\text { Area } \\
\text { sampled (ha) }\end{array}$ & $\begin{array}{c}\text { Units } \\
\text { sampled }\end{array}$ & $\begin{array}{c}\text { Percentage of } \\
\text { stratum } \\
\text { surveyed }\end{array}$ & $\begin{array}{c}\text { Survey } \\
\text { time (min) }\end{array}$ & $\begin{array}{c}\text { Survey } \\
\text { intensity } \\
\left(\mathbf{m i n} / \mathbf{k m}^{2}\right)\end{array}$ & $\begin{array}{c}\text { Number of } \\
\text { goats }\end{array}$ \\
\hline Klahhane SMC & 2,041 & 1 & 2,041 & 1 & 100 & 74.5 & 3.7 & 11 \\
High & 7,606 & 10 & 7,606 & 10 & 100 & 406.0 & 5.3 & 155 \\
Medium & 20,599 & 41 & 10,811 & 22 & 52 & 514.4 & 4.8 & 50 \\
Low & 29,369 & 56 & 3,001 & 6 & 10 & 111.4 & 3.7 & 1 \\
\hline Total & 59,615 & 108 & 23,458 & 39 & 39 & $1,106.3$ & 4.7 & 217 \\
\hline
\end{tabular}


Table 2. Population estimates of mountain goats, associated components of variance, standard errors, and 95-percent confidence intervals in the Olympic Mountains survey zone, Washington, 2004-2011.

[For comparison among years, estimates in 2011 are computed for two survey unit definitions: the expanded survey unit boundaries, which included suitable habitats above 1,425 m elevation, and the original survey unit boundaries including lands above 1,520 m elevation. For comparability, both survey definitions exclude the Mount Washington Survey Unit in the southeastern Olympic Mountains, which was not surveyed in 2011]

\begin{tabular}{|c|c|c|c|c|c|c|c|c|}
\hline \multirow[b]{2}{*}{ Year } & \multirow{2}{*}{$\begin{array}{l}\text { Survey unit } \\
\text { definition }\end{array}$} & \multirow{2}{*}{$\begin{array}{l}\text { Estimate } \\
\text { (Number } \\
\text { of goats) }\end{array}$} & \multicolumn{4}{|c|}{ Variance component ${ }^{1}$} & \multirow[b]{2}{*}{$\begin{array}{c}\text { Standard } \\
\text { error }^{2}\end{array}$} & \multirow{2}{*}{$\begin{array}{c}95 \text { percent } \\
\text { confidence } \\
\text { interval }^{3}\end{array}$} \\
\hline & & & Total & Sampling & Detection & Modeling & & \\
\hline 2011 & Expanded & 344 & 1,924 & 1,212 & 432 & 280 & 44 & $258-430$ \\
\hline 2011 & Original & 303 & 1,668 & 1,048 & 388 & 232 & 41 & $223-383$ \\
\hline 2004 & Original & 217 & 375 & 137 & 160 & 78 & 19 & $180-254$ \\
\hline
\end{tabular}

${ }^{1}$ Variance components as defined by Steinhorst and Samuel (1989) were computed following Wong (1996).

${ }^{2}$ Computed as square root of total variance.

${ }^{3}$ Computed as estimate $\pm 1.96(\mathrm{SE})$. 


\section{Appendix 1. Incidental Observations of Other Wildlife Species by Survey Unit, Olympic Mountains, Washington, 2011.}

[The number of individuals observed in the lower elevation survey zone newly designated in 2011 is listed in parentheses. Stratum: SMC, Special Management Concern; H, high density; M, medium density; L, low density]

\begin{tabular}{|c|c|c|c|c|c|c|c|}
\hline Stratum & Unit & Bear & Deer & Elk & $\begin{array}{c}\text { Golden } \\
\text { Eagle }\end{array}$ & Marmot & $\begin{array}{c}\text { Band-tailed } \\
\text { Pigeon }\end{array}$ \\
\hline SMC & 1 & $3(1)$ & 5 & & 1 & 2 & \\
\hline $\mathrm{H}$ & 69 & $1(1)$ & 4 & $3(3)$ & & & \\
\hline $\mathrm{H}$ & 93 & & & & & & \\
\hline $\mathrm{H}$ & 115 & & & & & & \\
\hline $\mathrm{H}$ & 125 & $4(3)$ & 2 & $1(1)$ & & & \\
\hline $\mathrm{H}$ & $127 N$ & & & & & & \\
\hline $\mathrm{H}$ & $127 S$ & & & & & & \\
\hline $\mathrm{H}$ & 129 & 1 & & & & & \\
\hline $\mathrm{H}$ & 131 & $1(1)$ & & & & & \\
\hline $\mathrm{H}$ & 137 & $4(3)$ & $3(3)$ & & & & \\
\hline $\mathrm{H}$ & 141 & $1(1)$ & & $24(24)$ & & & \\
\hline$M$ & 48 & $2(1)$ & & & & & \\
\hline$M$ & 54 & & & & & & \\
\hline$M$ & 55 & & 5 & & & & \\
\hline$M$ & 65 & & & & & & \\
\hline$M$ & 72 & & 3 & & & & \\
\hline$M$ & $73 E$ & 1 & & $10(10)$ & & & \\
\hline$M$ & $73 W$ & 2 & & & & & \\
\hline$M$ & 76 & 2 & & & & & \\
\hline$M$ & $81 \mathrm{E}$ & & & & & & \\
\hline$M$ & 83 & $1(1)$ & & & & & \\
\hline$M$ & 91 & 2 & & & & & \\
\hline$M$ & 94 & & & & & & \\
\hline$M$ & 95 & & & & & & \\
\hline$M$ & 97 & & & & & & 1 \\
\hline$M$ & $116 \mathrm{E}$ & & & & & & \\
\hline$M$ & 117 & 4 & & & & & \\
\hline$M$ & 122 & & & & & & \\
\hline$M$ & 123 & & & & & & \\
\hline$M$ & 124 & & & & & & \\
\hline$M$ & 130 & & & & & & \\
\hline$M$ & 132 & & & 8 & & & \\
\hline$M$ & 135 & $3(2)$ & & & & & \\
\hline L & 22 & 2 & 2 & & 1 & & \\
\hline L & 41 & & & & & & \\
\hline L & 50 & & & & & & \\
\hline L & 64 & & & & & & \\
\hline L & 87 & & & & & & \\
\hline L & 140 & $1(1)$ & 1 & & & & \\
\hline Totals & & 35 (15) & $25(3)$ & $46(38)$ & 2 & 2 & 1 \\
\hline
\end{tabular}




\section{Appendix 2. Trends in Other Wildlife Species Seen during Goat Surveys in the Olympic Mountains,}

Washington, 1983-2011.

Observations are scaled to a 500-ha basis to adjust for variable amount of area surveyed over the years. Counts have not been adjusted to account for detection bias or to account for changes in survey unit boundaries among years.

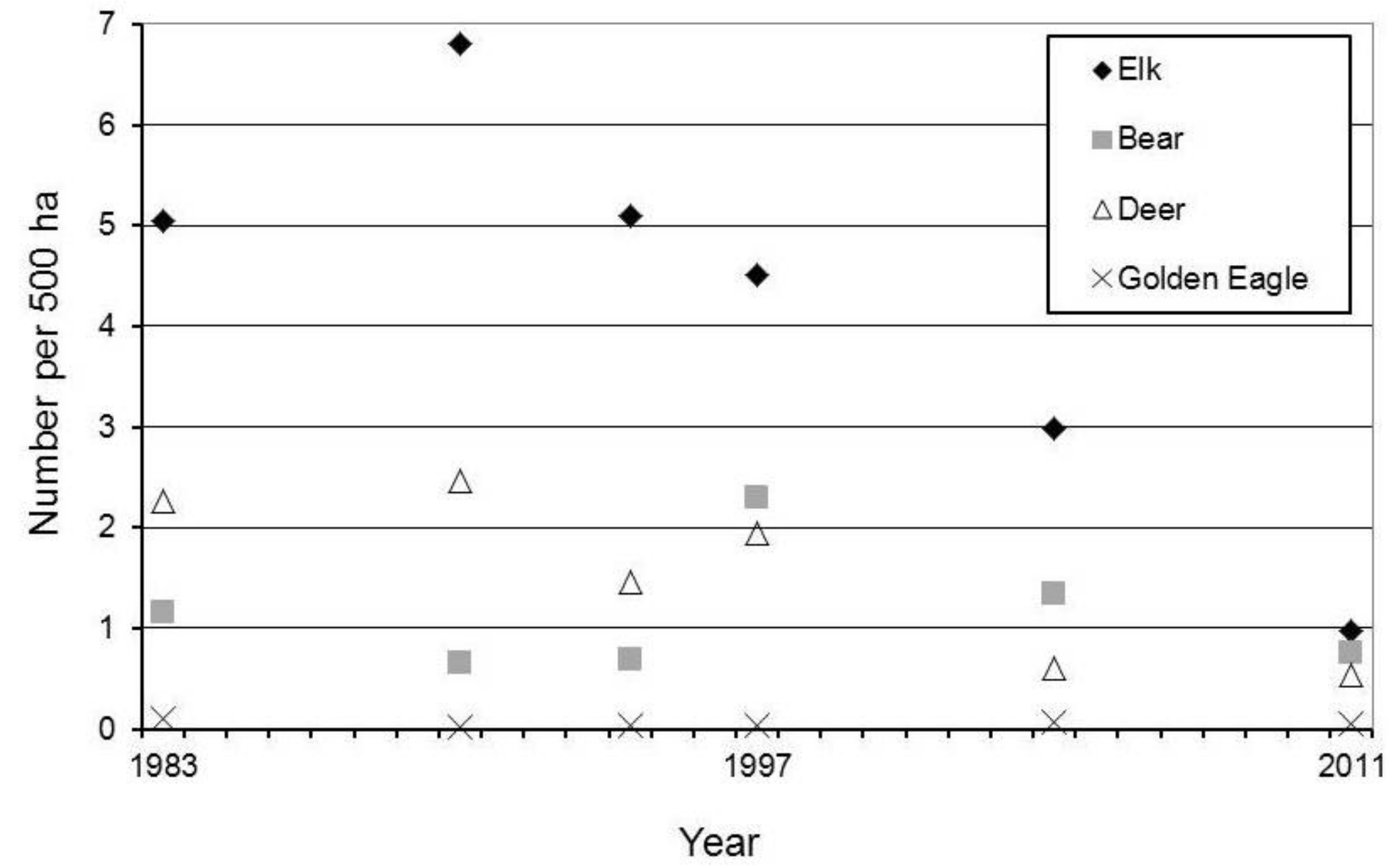




\section{Appendix 3. Survey Flight Characteristics during Aerial Mountain Goat Surveys, Olympic Mountains, Washington, 2011.}

[All surveys were conducted using a MD-500D aircraft piloted by Trever Walker, Northwest Helicopters. The total flight time, not including transit times from and to Olympia, was 1,629 minutes, including 1,106 minutes on survey. min, minutes; Mtn, mountain]

\begin{tabular}{|c|c|c|c|c|c|c|c|c|c|c|}
\hline \multirow[b]{2}{*}{$\begin{array}{c}\text { Flight } \\
\text { No. }\end{array}$} & \multirow[b]{2}{*}{ Date } & \multirow{2}{*}{$\begin{array}{c}\text { Departure } \\
\text { time } \\
\text { (a.m.) }\end{array}$} & \multirow{2}{*}{$\begin{array}{l}\text { Departure } \\
\text { location }\end{array}$} & \multirow{2}{*}{$\begin{array}{c}\text { Arrival } \\
\text { Time } \\
\text { (a.m.) }\end{array}$} & \multirow{2}{*}{ Arrival location } & \multirow{2}{*}{$\begin{array}{l}\text { Flight } \\
\text { duration } \\
\text { (min) }\end{array}$} & \multirow{2}{*}{$\begin{array}{c}\text { Survey } \\
\text { duration } 1 \\
\text { (min) }\end{array}$} & \multicolumn{3}{|c|}{ Observer/Seating position } \\
\hline & & & & & & & & Left back ${ }^{2}$ & Right front ${ }^{3}$ & Right back ${ }^{4}$ \\
\hline 1 & $7 / 18 / 11$ & $5: 40$ & Port Angeles & $7: 15$ & Blue Mtn & 95.0 & 59.0 & Beirne & Happe & Baccus \\
\hline 2 & $7 / 18 / 11$ & $7: 34$ & Blue Mtn & $9: 08$ & Blue Mtn & 94.0 & 64.2 & Beirne & Happe & Griffin \\
\hline 3 & $7 / 18 / 11$ & $9: 36$ & Blue Mtn & 10:51 & Port Angeles & 75.0 & 39.3 & Beirne & Happe & Griffin \\
\hline 4 & $7 / 19 / 11$ & $5: 40$ & Port Angeles & $7: 12$ & Blue Mtn & 92.0 & 47.6 & Beirne & Happe & Baccus \\
\hline 5 & $7 / 19 / 11$ & $7: 35$ & Blue Mtn & $9: 16$ & Blue Mtn & 101.0 & 74.6 & Beirne & Happe & Baccus \\
\hline 7 & $7 / 22 / 11$ & $5: 27$ & Port Angeles & $7: 10$ & Blue Mtn & 103.0 & 62.1 & Beirne & Happe & Baccus \\
\hline 8 & $7 / 22 / 11$ & $7: 26$ & Blue Mtn & 9:09 & Blue Mtn & 103.0 & 69.9 & Beirne & Happe & Baccus \\
\hline 9 & $7 / 22 / 11$ & $9: 25$ & Blue Mtn & 10:50 & Port Angeles & 85.0 & 53.0 & Beirne & Happe & Griffin \\
\hline 10 & $7 / 23 / 11$ & $5: 30$ & Port Angeles & 7:05 & Blue Mtn & 95.0 & 64.5 & Beirne & Happe & Baccus \\
\hline 11 & $7 / 23 / 11$ & $7: 24$ & Blue Mtn & 9:02 & Blue Mtn & 98.0 & 52.1 & Beirne & Baccus & Happe \\
\hline 12 & $7 / 23 / 11$ & $9: 18$ & Blue Mtn & 11:01 & Port Angeles & 103.0 & 61.4 & Beirne & Happe & Griffin \\
\hline 13 & $7 / 24 / 11$ & $5: 30$ & Port Angeles & 7:05 & Blue Mtn & 95.0 & 62.0 & Beirne & Jenkins & Baccus \\
\hline 16 & $7 / 25 / 11$ & $5: 40$ & Blue Mtn & $7: 21$ & Blue Mtn & 101.0 & 75.5 & Beirne & Jenkins & Griffin \\
\hline 17 & $7 / 25 / 11$ & $7: 39$ & Blue Mtn & 9:09 & Blue Mtn & 90.0 & 65.1 & Beirne & Jenkins & Griffin \\
\hline 18 & $7 / 25 / 11$ & $9: 26$ & Blue Mtn & $10: 56$ & Blue Mtn & 90.0 & 74.5 & Beirne & Happe & Griffin \\
\hline 19 & $7 / 25 / 11$ & $11: 08$ & Blue Mtn & 11:46 & Blue Mtn & 38.0 & 19.6 & Beirne & Happe & Griffin \\
\hline
\end{tabular}

${ }^{\mathrm{T}}$ Total time spent on surveys excluding time spent flying to and among survey units.

${ }^{2}$ Navigator: operated GPS during surveys.

${ }^{3}$ Primary observer: focused on searching for goats at all times.

${ }^{4}$ Data recorder: recorded all observations and covariate data. 


\section{Appendix 4. Survey Characteristics and Environmental Conditions Measured at the Beginning of Each Unit Surveyed in the Olympic Mountains, Washington, 2011.}

[Polygons are subunits that are used for data recording and survey planning. Duration of survey within each surveyed unit. Ppt: Precipitation level. Elevation at which air temperature was recorded. Illumination refers to lighting conditions during the survey. High contrast lighting casts shadows whereas flat lighting does not. ${ }^{\circ} \mathrm{C}$, degrees Celsius; ft, feet; min, minutes; $\mathrm{km}^{2}$, square kilometer]

\begin{tabular}{|c|c|c|c|c|c|c|c|c|c|c|c|c|c|}
\hline $\begin{array}{l}\text { Flight } \\
\text { No. }\end{array}$ & Date & $\begin{array}{l}\text { Unit } \\
\text { ID }\end{array}$ & $\begin{array}{l}\text { Polygon } \\
\text { ID(s) }\end{array}$ & $\begin{array}{l}\text { Unit } \\
\text { area } \\
\left(\mathrm{km}^{2}\right)\end{array}$ & $\begin{array}{c}\text { Survey } \\
\text { duration } \\
\text { (min) }\end{array}$ & $\begin{array}{c}\text { Survey } \\
\text { intensity } \\
(\mathrm{min} / \\
\left.\mathrm{km}^{2}\right)\end{array}$ & $\begin{array}{c}\text { Sky } \\
\text { condition }\end{array}$ & Winds & Ppt & $\begin{array}{l}\text { Cloud } \\
\text { cover } \\
\text { (per- } \\
\text { cent) }\end{array}$ & $\begin{array}{c}\text { Temp } \\
\left({ }^{\circ} \mathrm{C}\right)\end{array}$ & $\begin{array}{l}\text { Elevation } \\
\text { (ft) }\end{array}$ & Illumination \\
\hline 1 & $7 / 18 / 2011$ & 115 & 114,115 & 6.08 & 33.2 & 5.5 & clear & calm & none & 0 & 5 & 6,500 & high \\
\hline 2 & $7 / 18 / 2011$ & 122 & 122 & 3.99 & 29.6 & 7.4 & clear & calm & none & 0 & 8 & 5,800 & high \\
\hline 2 & $7 / 18 / 2011$ & 123 & 123 & 6.98 & 34.6 & 5.0 & clear & calm & none & 0 & 3 & 7,000 & high \\
\hline 4 & $7 / 19 / 2011$ & 93 & 93 & 5.78 & 30.7 & 5.3 & mostly clear & light & none & 20 & 10 & 5,500 & high \\
\hline 5 & $7 / 19 / 2011$ & 137 & 137,139 & 12.44 & 67.4 & 5.4 & mostly cloudy & calm & none & 80 & 5 & 6,000 & flat \\
\hline 5 & $7 / 19 / 2011$ & 135 & 136 & 1.97 & 7.2 & 3.7 & mostly cloudy & calm & none & 80 & 9 & & flat \\
\hline 6 & $7 / 19 / 2011$ & 140 & 140 & 6.01 & 23.4 & 3.9 & mostly clear & light & & 80 & 6 & 4,000 & high \\
\hline 6 & $7 / 19 / 2011$ & 135 & 135 & 1.53 & 6.6 & 4.3 & mostly clear & light & none & 40 & 6 & 5,300 & high \\
\hline 9 & $7 / 22 / 2011$ & 129 & 129 & 6.67 & 23.5 & 3.5 & mostly clear & moderate & none & 10 & 7 & 4,500 & high \\
\hline 9 & $7 / 22 / 2011$ & 130 & 130 & 5.84 & 29.5 & 5.1 & mostly clear & light & none & 5 & 8 & 6,300 & high \\
\hline 10 & $7 / 23 / 2011$ & 69 & $103,78,69$ & 14.19 & 64.5 & 4.5 & clear & light & none & 0 & 8 & 4,000 & high \\
\hline 11 & $7 / 23 / 2011$ & 97 & 97 & 2.74 & 15.4 & 5.6 & clear & calm & none & 0 & 11 & 5,000 & high \\
\hline 11 & $7 / 23 / 2011$ & 94 & 94 & 6.19 & 27.6 & 4.5 & clear & calm & none & 0 & 11 & & high \\
\hline 11 & $7 / 23 / 2011$ & 95 & 95 & 2.20 & 9.2 & 4.2 & clear & calm & none & 0 & 11 & & high \\
\hline 11 & $7 / 23 / 2011$ & 87 & 89 & 2.24 & 12.0 & 5.4 & clear & calm & none & 0 & 11 & 5,300 & high \\
\hline
\end{tabular}


Appendix 4. - Continued

\begin{tabular}{|c|c|c|c|c|c|c|c|c|c|c|c|c|c|}
\hline $\begin{array}{l}\text { Flight } \\
\text { No. }\end{array}$ & Date & $\begin{array}{l}\text { Unit } \\
\text { ID }\end{array}$ & $\begin{array}{c}\text { Polygon } \\
\text { ID(s) }\end{array}$ & $\begin{array}{l}\text { Unit } \\
\text { area } \\
\left(\mathrm{km}^{2}\right)\end{array}$ & $\begin{array}{c}\text { Survey } \\
\text { duration } \\
\text { (min) }\end{array}$ & $\begin{array}{c}\text { Survey } \\
\text { intensity } \\
(\mathrm{min} / \\
\left.\mathrm{km}^{2}\right)\end{array}$ & $\begin{array}{c}\text { Sky } \\
\text { condition }\end{array}$ & Winds & Ppt & $\begin{array}{l}\text { Cloud } \\
\text { cover } \\
\text { (per- } \\
\text { cent) }\end{array}$ & $\begin{array}{l}\text { Temp } \\
\left({ }^{\circ} \mathrm{C}\right)\end{array}$ & $\begin{array}{c}\text { Elevation } \\
\text { (ft) }\end{array}$ & Illumination \\
\hline 12 & $7 / 23 / 2011$ & $81 \mathrm{E}$ & $81 \mathrm{E}$ & 4.71 & 25.6 & 5.4 & clear & calm & none & 0 & 11 & 5,500 & high \\
\hline 12 & $7 / 23 / 2011$ & 83 & 83 & 5.99 & 27.6 & 4.6 & clear & calm & none & 0 & 11 & 5,500 & high \\
\hline 12 & $7 / 23 / 2011$ & 87 & 87,88 & 2.04 & 8.2 & 4.0 & clear & calm & none & 0 & 11 & 5,500 & high \\
\hline 13 & $7 / 24 / 2011$ & 141 & 141,142 & 3.76 & 24.1 & 6.4 & clear & light & none & 0 & 15 & 5,000 & flat \\
\hline 13 & $7 / 24 / 2011$ & 131 & 131 & 6.66 & 30.7 & 4.6 & clear & light & none & 0 & 20 & 4,800 & high \\
\hline 13 & $7 / 24 / 2011$ & 117 & 117 & 1.74 & 7.1 & 4.1 & clear & light & none & 0 & 20 & 5,500 & high \\
\hline 14 & $7 / 24 / 2011$ & 76 & 76 & 5.37 & 29.0 & 5.4 & clear & light & none & 0 & & & high \\
\hline 14 & $7 / 24 / 2011$ & $73 E$ & $73 E$ & 4.44 & 19.5 & 4.4 & clear & light & none & 30 & & & high \\
\hline 14 & $7 / 24 / 2011$ & $73 W$ & $73 W$ & 3.01 & 26.0 & 8.6 & mostly clear & light & none & 30 & 20 & 4,800 & high \\
\hline 15 & $7 / 24 / 2011$ & 65 & $65 W$ & 3.99 & 20.0 & 5.0 & clear & light & none & 10 & 20 & 6,000 & high \\
\hline 15 & $7 / 24 / 2011$ & 64 & 64 & 4.13 & 11.9 & 2.9 & mostly clear & light & none & 20 & 20 & 6,000 & high \\
\hline 15 & $7 / 24 / 2011$ & 41 & 41 & 5.65 & 13.7 & 2.4 & mostly clear & light & none & 3 & 20 & 6,000 & high \\
\hline 16 & $7 / 25 / 2011$ & 54 & 54 & 5.12 & 15.0 & 2.9 & mostly cloudy & calm & light & 65 & 14 & 6,200 & flat \\
\hline 16 & $7 / 25 / 2011$ & 55 & 55 & 5.08 & 18.2 & 3.6 & mostly cloudy & calm & none & 45 & 14 & 6,200 & flat \\
\hline 16 & $7 / 25 / 2011$ & 50 & 50 & 5.00 & 27.2 & 5.4 & mostly cloudy & calm & none & 80 & 12 & 6,000 & flat \\
\hline 16 & $7 / 25 / 2011$ & 22 & 22 & 4.93 & 15.1 & 3.1 & mostly cloudy & calm & none & 70 & 12 & 6,000 & flat \\
\hline 17 & $7 / 25 / 2011$ & 48 & 48 & 6.87 & 23.0 & 3.3 & mostly cloudy & light & none & 85 & 14 & 5,100 & flat \\
\hline 17 & $7 / 25 / 2011$ & 72 & 72 & 6.49 & 30.2 & 4.7 & mostly cloudy & light & none & 90 & 15 & 5,600 & flat \\
\hline 17 & $7 / 25 / 2011$ & 117 & 118 & 3.30 & 12.0 & 3.6 & mostly cloudy & light & none & 95 & 15 & 4800 & flat \\
\hline 18 & $7 / 25 / 2011$ & 1 & $1-13$ & 20.41 & 74.5 & 3.7 & mostly cloudy & light & none & 60 & 16 & 4800 & flat \\
\hline 19 & $7 / 25 / 2011$ & 132 & 132 & 3.73 & 19.6 & 5.3 & overcast & moderate & none & 85 & 12 & 5600 & flat \\
\hline
\end{tabular}




\section{Appendix 5. Raw Counts of Mountain Goats by Survey Unit, Olympic Mountains, Washington, 2011.}

[For each unit, the number of mountain goats observed within the portion of the survey unit below 1,520 m elevation is noted in parentheses. Stratum: SMC, Special Management Concern; H, high density; M, medium density; L, low density]

\begin{tabular}{|c|c|c|c|c|c|}
\hline Stratum & Survey unit & Survey unit name & Total & Adults & Kids \\
\hline SMC & 1 & Klahhane Total Count & 11 & 8 & 3 \\
\hline $\mathrm{H}$ & 69 & Chimney Total Count & $27(1)$ & 24 & 3 \\
\hline $\mathrm{H}$ & 93 & Mount Skokomish & 13 & 11 & 2 \\
\hline $\mathrm{H}$ & 115 & Seattle & 1 (1) & 1 & 0 \\
\hline $\mathrm{H}$ & 125 & Olympus Total Count & $74(9)$ & 58 & 16 \\
\hline $\mathrm{H}$ & 129 & Glacier Meadows & 4 & 3 & 1 \\
\hline $\mathrm{H}$ & $127 \mathrm{~N}$ & Olympus Summit, North & $11(2)$ & 8 & 3 \\
\hline $\mathrm{H}$ & $127 \mathrm{~S}$ & Olympus Summit, South & 0 & 0 & 0 \\
\hline $\mathrm{H}$ & 131 & Mount Childs & 0 & 0 & 0 \\
\hline $\mathrm{H}$ & 137 & Carrie Total Count & 25 & 23 & 2 \\
\hline $\mathrm{H}$ & 141 & Bogachiel Peak & 0 & 0 & 0 \\
\hline$M$ & 48 & Mount Fromme & 0 & 0 & 0 \\
\hline$M$ & 54 & Sunnybrook Meadows & 0 & 0 & 0 \\
\hline$M$ & 55 & Home Lake & 0 & 0 & 0 \\
\hline$M$ & 65 & Mount Constance, West & 0 & 0 & 0 \\
\hline$M$ & 72 & Eel & 0 & 0 & 0 \\
\hline$M$ & $73 E$ & Mount Anderson, East & 0 & 0 & 0 \\
\hline$M$ & $73 W$ & Mount Anderson, West & 15 & 12 & 3 \\
\hline$M$ & 76 & Diamond South & 5 & 3 & 2 \\
\hline$M$ & $81 \mathrm{E}$ & Mount Steel, East & 11 & 11 & 0 \\
\hline$M$ & 83 & LaCrosse & 0 & 0 & 0 \\
\hline$M$ & 91 & Mount Gladys & 0 & 0 & 0 \\
\hline$M$ & 94 & Mount Stone & 0 & 0 & 0 \\
\hline M & 95 & Mount Hopper & 0 & 0 & 0 \\
\hline$M$ & 97 & Mount Bretherton & 0 & 0 & 0 \\
\hline$M$ & $116 \mathrm{E}$ & Mount Queets, East & 0 & 0 & 0 \\
\hline$M$ & 117 & Dana & 0 & 0 & 0 \\
\hline$M$ & 122 & Valhallas, North & $11(5)$ & 11 & 0 \\
\hline$M$ & 123 & Humes Glacier & $6(6)$ & 3 & 3 \\
\hline$M$ & 124 & Mount Barnes & 1 & 1 & 0 \\
\hline$M$ & 130 & Mount Mathias & 0 & 0 & 0 \\
\hline$M$ & 132 & Ludden Peak & 0 & 0 & 0 \\
\hline$M$ & 135 & Scott/Dodger & 1 & 1 & 0 \\
\hline L & 22 & Badger & 0 & 0 & 0 \\
\hline L & 41 & Grey Wolf North & 0 & 0 & 0 \\
\hline L & 50 & Wellesley Peak & 1 & 1 & 0 \\
\hline L & 64 & The Gargoyles & 0 & 0 & 0 \\
\hline L & 87 & Jupiter & 0 & 0 & 0 \\
\hline $\mathrm{L}$ & 140 & Mount Fitzhenry & 0 & 0 & 0 \\
\hline TOTALS & & & 217 & 179 & 38 \\
\hline
\end{tabular}


Publishing support provided by the U.S. Geological Survey Publishing Network, Tacoma Publishing Service Center

For more information concerning the research in this report, contact the Director, Forest and Rangeland Ecosystem Science Center

U.S. Geological Survey

777 NW 9th Street, Suite 400

Corvallis, Oregon, 97330

http://fresc.usgs.gov/ 
离

홀

를

웋

ए

을

旁

웅

를

행

䓂

음

훙

쿨

寻

음

름

흘

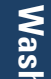

言

흠

옴

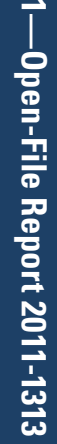

